\title{
Tecnologias de realidade virtual imersivas como ferramenta terapêutica para o isolamento social em tempos de pandemia
}

\section{Immersive virtual reality technologies as a therapeutic tool for social isolation in pandemic times}

M. Melo

EDITORIAL | EDITORIAL

O ano de 2020 apresentou-nos novos desafios que nunca pensaríamos atravessar. Nomeadamente, uma epidemia global devido ao novo coronavívurs CoViD-19 que impôs o isolamento social a uma grande parte do mundo, senão a todo o mundo mesmo. Sendo que o ser humano é, por natureza, um ser social e que a sua interação como o meio e com os outros permite-lhe desenvolver seu próprio "eu", o isolamento social imposto pela pandemia trouxe grandes desafios à sociedade, provocando a consequências não só ao nível da saúde física mas sobretudo a nível da saúde mental, incluindo depressão e ansiedade. Existem mesmo estudos que indicam que $\mathrm{o}$ isolamento social pode aumentar em cerca $29 \%$ o risco de doenças cardíacas e em cerca de $32 \%$ o risco de acidentes vasculares cerebrais.

É com os olhos postos nestes desafios societais que existe a motivação de querer fazer mais e melhor tirando partida das ferramentas tecnológicas. $\mathrm{Na}$ verdade, as tecnologias de realidade virtual imersivas podem ser muito importantes para o combate a este flagelo social. As tecnologias de realidade virtual permitem a construção de ambientes virtuais com os quais os seus utilizadores podem interagir como se estivessem dentro desses mesmos ambientes, criando um fenómeno psicológico de presença no mundo virtual tal como se estivessem num ambiente real. Com a evolução da tecnologia, o potencial desses ambientes virtuais cresceu imenso sendo que hoje em dia já é possível obter ambientes virtuais hiper-realistas. Para além disso, já é possível ao cidadão comum adquirir equipamentos que permitem experiências imersivas de alta qualidade através de óculos de realidade virtual a um custo acessível. Assim sendo, resta-nos tirar partido desta oportunidade oferecida pela tecnologia de transportar um utilizador para um outro sítio sem sair de casa.

As tecnologias de realidade virtual imersivas podem ser uma ferramenta terapêutia muito muito importante para o combate ao isolamento social causado pela pandemia. Numa primeira fase, a tecnologia resumia-se à visualização de fotografias em $360^{\circ}$ que posteriormente evoluiu para a utilização de vídeos $360^{\circ}$. No entanto, este tipo de conteúdos apresenta uma limitação: estamos sempre limitados ao ponto de vista da câmara e não era possível aos utilizadores navegar ou interagir com o ambiente virtual. Um grande progresso neste campo foi a utilização de técnicas de fotogrametria para a síntese de ambientes virtuais hiper realistas. Para tal, recorre-se a uma extensiva recolha fotográfica do local a representar virtualmente e, através de técnicas de computação avançada 
de processamento digital de imagem para a criação de ambientes virtuais 3D fidedignos. Uma vez obtidos estes ambientes virtuais 3D, é possível criar aplicações de realidade virtual que permitem a navegação dos utilizadores por estes tipos de ambientes tal como se estivessem verdadeiramente a visitar um local real. Para além disso, é possível complementar o ambiente com funcionalidades colaborativas onde várias pessoas, mesmo que localizadas em pontos físicos distantes, podem interagir em conjunto tal como se estivessem juntos no mesmo local. Estes avanços tecnológicos recentes carecem de um estudo aprofundado sobre o seu potencial de aplicação em diferentes contextos e os seus efeitos a nível da psique.

Assim, mais uma vez, o uso das tecnologias é um mundo cheio de oportunidades para melhorar o quotidiano daqueles que estão expostos ao isolamento social, quer seja voluntário ou involuntário. Este tipo de tecnologias pode despertar sensações positivas e fazer com que as pessoas se sintam mais confortáveis, otimistas e ligadas com o mundo exterior, dinamizando assim o seu bem-estar através da interação social.

Com os olhos postos no fomento de trabalhos que liguem as áreas da tecnologia e da psicologia, é com ousadia que desafiamos todos os autores e leitores da PsychTech \& Health Journal a refletirem sobre esta temática que assola um número considerável de pessoas no mundo inteiro e que desenvolvam e publiquem connosco trabalhos cujo objetivo é a utilização das tecnologias para a melhoria da qualidade de vida da população em geral. 